\title{
DIAGNÓSTICO DA QUALIDADE DO TRANSPORTE COLETIVO SOB A ÓTICA DO USUÁRIO NA CIDADE DE PATO BRANCO/PR
}

\author{
K. F. Rubio' ${ }^{1}$ D. R. Bisconsini ${ }^{2}$ \\ 1,2 Departamento de Engenharia Civil - UTFPR, Campus Pato Branco, Departamento de Construção Civil, Via \\ do Conhecimento, km 01, PR. Tel: 55-46-3220-2511 \\ krubio@alunos.utfpr.edu.br ${ }^{l}$, bisconsini@utfpr.edu.br ${ }^{2}$
}

\begin{abstract}
Resumo: Um dos grandes gargalos do sistema viário dos municípios brasileiros é o uso massivo do transporte individual em detrimento ao uso do transporte coletivo. Neste estudo, serão determinados os pontos positivos e negativos do sistema de transporte coletivo da cidade de Pato Branco/PR, tomando-se como referência a percepção do usuário. Será determinado seu grau de satisfação e os fatores críticos redutores de qualidade, seguidos da proposição de medidas para a melhoria do sistema. O método aplicado inclui uma revisão bibliográfica relacionada ao tema, aplicação de pesquisa de satisfação e um processamento e análise das informaçóes obtidas. Resultados preliminares apontam certa insatisfação com o transporte coletivo, sendo os fatores críticos redutores de satisfação a superlotaçáo dos ônibus, o longo intervalo entre ônibus e a dificuldade de acesso à informaçóes sobre rotas, horários e canais de informaçóes e reclamaçôes.
\end{abstract}

Palavras-chave: Transporte público, Mobilidade, Satisfação dos usuários.

\section{Introduçáo}

O contínuo crescimento da população e distâncias percorridas é a realidade de muitas cidades brasileiras, onde o transporte individual prevalece sobre o transporte coletivo. Conforme [1], 39\% dos brasileiros considera o transporte coletivo ruim ou muito ruim e $31,3 \%$ regular. O objetivo deste estudo consiste em obter, sob a ótica do usuário, os pontos positivos e negativos do sistema de transporte coletivo na cidade de Pato Branco/PR, os quais servirão como base na proposição de melhorias do sistema.

\section{Metodologia}

A metodologia inclui uma revisão bibliográfica acerca da qualidade do transporte coletivo por ônibus, indicadores e pesquisas com usuários. Baseado nos critérios propostos por [2], foi elaborado um questionário eletrônico destinado aos usuários do transporte coletivo de Pato Branco/ PR, o qual foi divulgado e disponibilizado em grupos de redes sociais de abrangência municipal. $\mathrm{O}$ mesmo questionário foi impresso e apresentado a uma parcela de usuários em pontos de embarque e desembarque. Na sequência, foi realizado um tratamento dos dados que permitiu a identificar o grau de satisfação dos usuários perante o sistema de transporte público oferecido, além da determinação 
dos principais fatores de descontentamento, que interferem negativamente na qualidade do serviço oferecido.

Adicionalmente, serão analisados dados sobre rotas, frota e quantidade de usuários disponibilizados pelo Departamento Municipal de Trânsito do Município de Pato Branco/PR (DEPATRAN), além da observação da condição dos pontos de parada e integração de ônibus. Em seguida, serão propostas medidas de melhorias que possam afetar positivamente a qualidade do serviço oferecido. Finalmente, serão realizadas entrevistas com especialistas da área, para que estes possam opinar sobre as propostas sugeridas.

\section{Resultados esperados}

Espera-se que os procedimentos adotados neste estudo possam servir como modelo para a análise da qualidade do transporte coletivo em outros municípios, com foco na indicação de intervençóes que afetem positivamente o serviço.

\section{Referências}

[1] INSTITUTO DE PESQUISA ECONÔMICA APLICADA (IPEA). Sistema de indicadores de percepçáo social (SIPS). 2011.

[2] FERRAZ, A. C. P.; TORRES, I. G. E. Transporte Público Urbano. 2. ed. São Carlos, SP: RiMa, 2004. 